\title{
Understandings and Tendencies of Edutainment in Turkey: An Evaluation Based on Neil Postman's Criticism on Education, Entertainment and Technology
}

\author{
Filiz Goktuna Yaylaci \\ Anadolu University, Turkey \\ Ali Faruk Yaylaci \\ Recep Tayyip Erdogan University, Turkey
}

\begin{abstract}
There have been a wide range of studies on the interplay between education and technology. Furthermore, there are many other studies aimed at analyzing the scholarly output on this subject with a holistic approach. However the studies are mostly focused on the facilitator role of technology. Although the idea that educational processes have become more fun, thanks to the widespread use of technology, there is a strong need for the critical analysis of the interplay among education, entertainment and technology. Taking this need into account, and drawing on Neil Postman's critical approach on this trio, this article aims to discuss and evaluate the tendencies and understandings in relation to the notion of "edutainment" primarily with reference to "edutainment" studies carried out in Turkey. It is expected that this evaluation would contribute to similar future studies, thus helping the policy development. According to findings of the study, although the edutainment studies in Turkey reflect the general tendency throughout the world, there only a few of them quantitatively. There is no consensus on the designation and definition of the concept of edutainment. From Postman's point of view, it could be said that edutainment studies in Turkey lack a critical perspective with regard to technology and entertainment, and there is a quite limited framework.
\end{abstract}

Keywords: Edutainment; Educational technology; Entertainment; Technopoly; Neill Postman

\section{Introduction}

Educational organizations, educational processes as well as views and functions of teachers, administrators, students and parents concerning educational processes are influenced by technological developments. In different ways and with an increasing intensity, technology is transforming the education for almost all stakeholders. Edutainment is one of the most original example of this transformation. In this study we aimed to evaluate the edutainment studies in Turkey based on Postman's legacy. In this regard it could be very useful to mention edutainment's history and Postman's thoughts briefly.

When a grassroots movement that started in households in early 1980s put pressure on schools to ensure that the computers are brought into classrooms, people started to think that the initiation of the use of computers in classrooms was a revolution (Molnar \& Deringer, 
1984). The transformation process which started with the use of computers in classrooms caused the interaction between education and technology to gain new dimensions. While the educational processes were revolutionized, the impact of technology on education continued to be an important matter of debate. Technology has transformed the nature of educational processes, teaching methods, individual learning and also expectations from the school. As a result of the gradual spread of innovations in the field of education and communication, new methods and approaches emerged with new software and hardware. This situation has caused an educational understanding that pays regard to the active participation of students, their individual preferences and individual learning methods and tools (Sorathia \& Servidio, 2012; Goffe \& Sosin, 2005).

The transformation that occurred in educational systems is not over. As indicated by Anikina and Yakimenko (2015), there is an ongoing search for more interactive learning methods, which also further attract the students to itself, as well as the educational transformation and transition. At the same time fast and remarkable developments in communication and information technologies have produced remote education which has no spatial and time constraints (Yamamoto \& Watanabe, 2013).

We are living in a world, where technology is formed in an unprecedented manner. This new world produces specific teaching and learning forms. The understandings regarding the objectives, content and quality of education try to harmonize with the current conditions in societies living in the new world of communication and information technologies. While the children live with hyper-speed of the age of information and communication, there are likely to be influenced with messages surrounding them. The media that produce reality designs shape the character of individuals and particularly the children (Alver, 2004; Pembecioglu, 1997). As indicated by Jarvin (2015), the children and adults spend most of their time for digital entertainment elements, and therefore new approaches aimed at responding to that situation and also directing that energy into self-motivated or self-regulated learning are needed in the education in digital era.

A tendency that can be discussed in this context is related with the concept of entertainment. Since the development of educational television in the 1960s, there has been a growing interest in incorporating features of entertainment in informal and formal education (Jarvin, 2015). Within the context of the combination of entertainment and educational processes, edutainment has emerged to define new tendencies. There are some considerations that the edutainment started with the initial involvement of computers in the classroom (Molnar \& Deringer, 1984). The edutainment in which technology and entertainment are combined for educational purposes has gained considerable acceptance.

When computer games started to be used for educational purposes on a large scale, what designated under the term edutainment became as a panacea for instruction (Charsky, 2010 cited in Jarvin, 2015). Edutainment as a modern and popular technology of education (Anikina \& Yakimenko, 2015) has become a trendy subject both for general public and academics. In spite of the increasing number of studies, theoretically deep studies are needed (Singhal \& Rogers, 2002). In conclusion, we can say that we live in the realm of edutainment (Katz, 2015), but it is important to carry out an analysis of the concept of edutainment with a critical perspective beyond the dominant approaches that consider technology with an almost natural optimism. 


\section{In Realm of Edutainment}

Entertainment-education, defined as the intentional placement of educational content in entertainment messages, has received increasing attention from communication scholars in recent decades. The first recognizable entertainment-education interventions, which could be considered as a preview of the edutainment, were launched on radio with The Archers in 1951, and on television with Simplemente María in 1969 (Singhal \& Rogers, 2002). The concept of edutainment has been used for computer games since 1970s (Aksakal, 2015). The edutainment could be basically seen as "the process of purposely designing and implementing a media message to both entertain and educate" (Singhal \& Rogers, 1999 cited in Singhal \& Rogers, 2002). It could be hardly said that there is consensus on the definition of edutainment, despite its relatively long history.

The concept of edutainment was firstly used in order to define the CD-ROOM programs which were used for edutainment purposes (Rapeepisam et al., 2006). The word edutainment is a concept that refers to a situation combining both the entertainment and education or the marriage between education and entertainment (Colace et al., 2006 cited in Aksakal, 2015) and edutainment cold be seen as an empirical application of the constructivism theory (Ozkal et al., 2009 cited in Sorathia \& Servidio, 2012).

Edutainment is a feature of the technology implementation of modern forms of entertainment in traditional lectures, lessons, classes, workshops and master classes. Without television programs, desktop, computer and video games, movies, music, web sites, multimedia software is already impossible to imagine a modern training and communication (Anikina \& Yakimenko, 2015).

Edutainment is the new technology of the real learning, consisting of the basic motivation of entertainment and happiness and focusing on the methodological understanding of the game and game technology. Edutainment is considered by the authors as a training concept used in training for the museums, environmental education, leisure centers, information and mass media (Nemec, Jiri \& Trna, 2007 cited in Anikina \& Yakimenko, 2015).

Although the computer technologies and edutainment are closely associated with each other, edutainment has more comprehensive definitions as well. Edutainment refers to a set of activities that could be realized in drama, story, television and computers (Aksakal, 2015). The virtual reality has been recently used within the context of edutainment. As De Paolis et al. (2009) stated, the virtual reality makes it possible to create applications for edutainment purposes for the general public.

Rapeepisam et al. (2006) pointed out the difference between learning through the gamebased learning and edutainment. According to the body of literature, while the game-based learning is likely to consist of activities with or without media, the edutainment is based on media.

Based on the common ground of the definitions of edutainment, it could be said that the basic characteristics of edutainment is to ensure that the learning process is made entertaining, learning is achieved by having a good time, the interest in learning is boosted and therefore it is rendered permanent. As a result, edutainment combines education with entertainment aspects; thus enhancing the learning environment, making it more engaging and funfilled. The 
most legitimizing aspect of edutainment is that it makes learning both entertaining and attractive (Aksakal, 2015; De Paolis et.al, 2009; Yamamoto \& Watanabe, 2013).

The theoretical discussions about edutainment reject the existence of a resistance (Singhal \& Rogers, 2002). There is a need for critical approaches within the context of edutainment. Nevertheless, it would not be wrong to argue that there are at least some concerns with regard to edutainment in the body of literature. One of the basic concerns are cited as the fact that the edutainment practices are considered as a structure not replacing the conventional education but supporting it. For example, Perushev as one of the supporters of edutainment in Russia notes that edutainment is the transfer of knowledge, opportunity to learn something new from reliable sources, and not an alternative to academic education (Perushev, 2009 cited in Anikina \& Yakimenko, 2015). Furthermore, possible drawbacks of the combination of education and entertainment in an environment occupied by media were mentioned as well. The convergence of education and entertainment is favored by the diffusion of technology and its use. The application of the new technologies to edutainment reinforces the convergence between education and entertainment (Addis, 2005). According to Singhal and Rogers (2002), in highly saturated media environments and to a somewhat lesser degree in developing countries, entertainment-education messages face competition from, and are resisted by, various other media discourses, which are usually of the "entertainment-degradation" or "entertainment-perversion" type.

\section{Education and Entertainment in Postman's Technopoly}

Entertainment itself is a concept, which is difficult to be defined with a common and single definition. A large variety of activities could be covered by the definition of entertainment and it varies across individuals. The basic function of the modern entertainment is likely to ensure that the individuals fatigued by the modern life are relaxed and returned back to that life or prevent individuals from going outside the system, while they relieve tiredness (Sener, 2016). In fact, as Bates and Ferri (2009) said, entertainment has been a part of all cultures, from the Chauvet Cave paintings to the iPad. But now entertainment is making increasing inroads into people's personal lives (Postman, 1985 cited in Singhal \& Rogers, 2002). Entertainment is becoming a more integral part of our shopping, traveling, eating, driving, exercising, and working experiences (Singhal \& Rogers, 2002).

The authorities dealing with the field of communication defined the entertainment experience with concepts of pleasure, joy, thrill, relaxation, diversion, and enjoyment (Wirth, Hofer \& Schramm, 2012). Similarly, the difference between hedonic and eudaimonic entertainment could be mentioned. What is experienced in the process of watching the movies with a happy ending is an example of the eudaimonic entertainment. The state of eudaimonic well-being has been transferred to entertainment (Wirth, Hofer \& Schramm, 2012). As Thompson (2007) and Kim and Vishak (2008) stressed that the idea that popular culture and entertainment media influence us in both conscious and unconscious ways is not new and gradually the entertainment media have begun to be recognized as an important venue of "infotaining" citizens. However as with traditional media, we need to view these spaces with a critical eye, especially as they gain popularity and advertising dollars. We also need to ask, who has the access, knowledge, and skills necessary to be the "you"s who shape the media? Whose voices are not being heard? How will this interactive medium influence individuals and society? The answers lie in the future (Thompson, 2007). 
Some people have identified the US as the "republic of entertainment" (Bates \& Ferri, 2009), but according to Postman (1993; 2013), the US is the single example of the technopoly. Technopoly paves a useful way for a discussion on the interaction between technology, education and entertainment.

At this stage, it would be useful to briefly touch upon Postman's concept of technology, his understanding of technopoly and his opinions on the relation between education and entertainment. According to Postman's (1998) understanding, we need to have a different point of view on the issue of technology and be on the alert:

In the past, we experienced technological change in the manner of sleep-walkers. Our unspoken slogan has been "technology über alles," and we have been willing to shape our lives to fit the requirements of technology, not the requirements of culture. This is a form of stupidity, especially in an age of vast technological change. We need to proceed with our eyes wide open so that we many use technology rather than be used by it (Postman, 1998).

Postman (2013) begins his book entitled "Technopoly" with the story of the Egyptian King Thamus, which he describes as considerably informative. According to him, the story told by Plato in his book entitled "Phaedrus" consists of several principles as to how to think with wise circumspection about technology. At this point, the warnings made by Thamus to Theuth, who has made complimentary remarks about the invention of writing, as well as his ideas that the writing would make it easier to have knowledge but damage wisdom. It could be argued that those who keep a wary eye on technology are represented in the person of Thamus, who says that making an invention and imagining if it would bring any benefit or harm are different from each other, and the group of technophiles are represented in the person of Theuth. According to Postman, there are five things we need to know about technological changes in order to be able to develop a point of view about technology (Postman, 1998):

a) The first idea is that all technological change is a trade-off. I like to call it a Faustian bargain. Technology giveth and technology taketh away. This means that for every advantage a new technology offers, there is always a corresponding disadvantage. Culture always pays a price for technology

b) The advantages and disadvantages of new technologies are never distributed evenly among the population. This means that every new technology benefits some and harms others.

c) Embedded in every technology there is a powerful idea, sometimes two or three powerful ideas. These ideas are often hidden from our view because they are of a somewhat abstract nature. To a person with a TV camera, everything looks like an image. To a person with a computer, everything looks like data.

d) Technological change is not additive; it is ecological. What happens if we place a drop of red dye into a beaker of clear water? Do we have clear water plus a spot of red dye? Obviously not. We have a new coloration to every molecule of water. A new medium does not add something; it changes everything. In the year 1500, after the printing press was invented, you did not have old Europe plus the printing press. You had a different Europe. After television, America was not America plus television. Television gave a new coloration to every 
political campaign, to every home, to every school, to every church, to every industry, and so on.

e) Media tend to become mythic. I use this word in the sense in which it was used by the French literary critic, Roland Barthes. He used the word "myth" to refer to a common tendency to think of our technological creations as if they were God-given, as if they were a part of the natural order of things. Cars, planes, TV, movies, newspapers - they have achieved mythic status because they are perceived as gifts of nature, not as artifacts produced in a specific political and historical context.

The above-mentioned five quotations refer to the key criteria of developing a deep and critical perspective regarding technology. The critical analysis concerning edutainment should also take these criteria into consideration.

According to Postman, there is an existential conflict between technology and human. He suggested the dominance of technology over everything has started with Comte. According to Postman, August Comte said at the beginning of the $19^{\text {th }}$ century that none of the invisible and mathematically non-concretizable things are real, and thus presented the measurable, countable and orientable human design of the future as an object. Frederick W. Taylor underlined the process of putting this idea into practice. Hereafter, the system has started to think and decide on behalf of the worker, instead of him/her thinking and deciding on his/her own. At this point, the first signs of the prospect of replacing the thought with technology in the future could be seen (Alver, 2004).

In Technopoly, modern secular education has no moral, social or intellectual center (Postman, 1993). With the rise of Technopoly, one of those thought-worlds disappears. Technopoly eliminates alternatives to itself in precisely the way Aldous Huxley outlined in Brave New World. It does not make them illegal. It does not make them immoral. It does not even make them unpopular. It makes them invisible and therefore irrelevant. And it does so by redefining what we mean by religion, by art, by family, by politics, by history, by truth, by privacy, by intelligence, so that our definitions fit its new requirements. Technopoly, in other words, is totalitarian technocracy (Postman, 1993, p.48).

\section{Purpose}

In Postman's (2013, p.8) own words, "technology is both friend and enemy." Accordingly, it deserves a cautious and also skeptical evaluation. The studies regarding the information technology in education are usually on a technical level (Conlon, 2002). This situation is valid to a great extent in terms of the studies conducted in Turkey as well. Although the edutainment is a new concept in Turkey in terms of its practical examples and as a research subject, it should be evaluated from a critical perspective. Within this context, this article aims to discuss and evaluate, the tendencies and understandings of "edutainment" with a specific reference to "edutainment" studies carried out in Turkey based on the views of Neil Postman's critics on technology, education and entertainment. We sought answers to the following questions towards that end:

a) What is the general situation about the years in which the studies on edutainment are published? 
b) How are the articles on edutainment distributed in terms of the number of their writers?

c) How are the studies on edutainment categorized in terms of their languages and naming of the concept in Turkish?

d) How are the articles on edutainment distributed in terms of the journals they are published?

e) How are the studies on edutainment distributed in terms of their fields?

f) How are the studies on edutainment distributed in terms of their approaches to edutainment?

g) What are the main results and suggestions of the studies on edutainment?

\section{Method}

\section{Research Model}

This study aimed to evaluate the tendencies of research on edutainment in Turkey. In this regard, the study was designed as a qualitative, descriptive study to make a comprehensive evaluation based on the edutainment studies in Turkey.

\section{Working Group}

Criterion or judgmental sampling technique was used to determine the studies for the working group of the study. In this way 25 published articles which are directly related edutainment constituted the working group. We preferred the term working group rather than sample because the range of the studies reviewed is relatively narrow.

\section{Procedures}

Document analysis was used to collect data. The data were analyzed based on the categories; naming of edutainment, method, type, field, approach towards edutainment, main results and suggestions. The data were analyzed through the frequency and categorical analyses. In the first phase, two researchers made a search to collect the articles related edutainment on the Internet. The articles were found on the Turkish Academic Network and Information Center (ULAKBIM), the Google Academic, Web of Science All Database. In the second phase, the year of publication, number of authors, journals covering the publication, language of the article and its field were separately analyzed by authors of the article in terms of the Turkish definitions, which were used to refer to the concept of education. The conclusions drawn by the articles, as well as their suggestions, were analyzed and expressed in the form of themes. In the third stage, authors discussed the tables and themes they have prepared on the basis of categories, and integrated the findings. The findings obtained and the conclusions drawn were discussed within the context of Postman's views on the interaction between technology, entertainment and education. 


\section{Findings}

The findings of the study are presented on the basis of the categories; the articles' publication years, author numbers, type, field, journals publishing the articles, naming of edutainment, approach towards edutainment, main results, and suggestions.

\section{Years of Publication for Articles}

Figure 1 exhibits the distribution of research studies on edutainment in Turkey by their years of publication. It is seen that the concept of edutainment has been mentioned for the first time in a study in 1998. A relative increase occurred in the number of publications on edutainment in the period covering 2009 and 2013. It is seen that there was a decrease again to a level of publication in the later years.

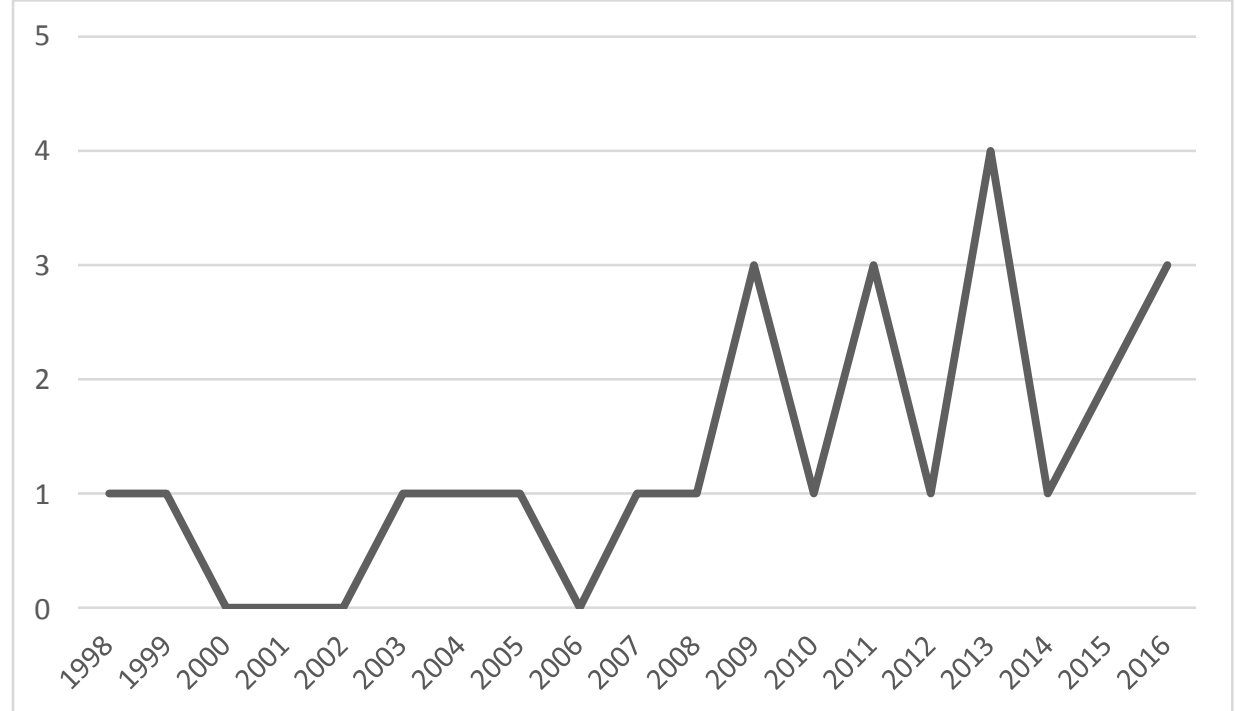

Figure 1. Articles on Edutainment by Years

\section{Number of Authors}

Table 1 shows the findings regarding the number of authors of the articles on edutainment. As seen on Table 1, nearly two-third of the articles (16 articles) on edutainment was written by one author. Five articles were written by two authors and one article was written by three authors. The total number of the authors publishing articles on edutainment in Turkey is 35 .

Table 1.

\begin{tabular}{ccc}
\hline Number of Authors & Number of Articles & Total Number of Authors in Articles \\
\hline 1 & 16 & 16 \\
2 & 8 & 16 \\
3 & 1 & 3 \\
Total & $\mathbf{2 5}$ & $\mathbf{3 5}$ \\
\hline
\end{tabular}




\section{Types of the Articles}

As seen on Table 2, most of the articles on edutainment are theoretical, literature reviews or qualitative studies. There are 3 quantitative research articles. Furthermore, there is one book review and one translated article.

Table 2. Methods and Types of Articles

\begin{tabular}{ll}
\hline Method/Type of the Articles & $\mathbf{f}$ \\
\hline Theoretical-Literature Review & 10 \\
Qualitative Study & 10 \\
Quantitative Study & 3 \\
Book Review & 1 \\
Translated Article-Literature Review & 1 \\
Total & $\mathbf{2 5}$ \\
\hline
\end{tabular}

\section{Fields of Articles}

Table 3 presents findings on fields regarding the contexts to which the articles on education are related or on which studies are carried out. As seen on Table 3, a distinct majority of the articles (15 articles) are in the field of education, learning and teaching technologies. Nearly one fourth of them are in the field of communication and media ( 6 articles), and there are two articles in the field of computer games and one in each of the fields of library sciences and linguistics.

Table 3. Fields of Articles on Edutainment

\begin{tabular}{ll}
\hline Field of Edutainment Studies & $\mathbf{f}$ \\
\hline Education, Learning and Instructional Technologies & 15 \\
Communication and Media & 6 \\
Computer Games & 2 \\
Library Sciences & 1 \\
Linguistics/Language & 1 \\
Total & $\mathbf{2 5}$ \\
\hline
\end{tabular}

\section{Journals Publishing the Articles}

Table 4 contains the finding on the journals that have featured the articles on edutainment. It demonstrates that a total of 19 edutainment-related articles were published in 17 different journals. Of the total number of studies published, 5 of them were published as part of conference proceedings, and one of them is based on a master thesis on foreign words in Turkish language. Half of the journals (9) are the ones publishing educational research, theory and practice, while 4 in social sciences and humanities, other 3 in communications, and the remaining 1 in natural sciences. Each of the Anadolu University's Turkish Online Journal of Distance Education and Istanbul University's Faculty of Communication Journal featured two edutainment articles as the others have published one article each. Table 4 demonstrates the journals in which articles on edutainment were published. 


\begin{tabular}{|l|c|}
\hline Journal & f \\
\hline Turkish Online Journal of Distance Education-TOJDE & 2 \\
\hline Istanbul University Faculty of Communication Journal & 2 \\
\hline Ondokuz Mayis University, Journal of Education Faculty & 1 \\
\hline International Journal of Eurasia Social Sciences & 1 \\
\hline Eurasian Journal of Educational Research & 1 \\
\hline Sigma Journal of Engineering and Natural Sciences & 1 \\
\hline ILETi-Ş-iM: Galatasaray University Journal of Communication & 1 \\
\hline Journal of Turkish Educational Sciences & 1 \\
\hline Marmara University Journal of Atatürk Educational Faculty & 1 \\
\hline A.U. Journal of Faculty of Languages, History and Geography & 1 \\
\hline Marmara Journal of Communication & 1 \\
\hline Kastamonu Education Journal & 1 \\
\hline Contemporary Educational Technology & 1 \\
\hline Rumeli Journal of Language and Literature Studies & 1 \\
\hline Journal of Research in Education and Teaching & 1 \\
\hline British Journal of Humanities and Social Sciences & 1 \\
\hline British Journal of Educational Technology & 1 \\
\hline Total & $\mathbf{1 9}$ \\
\hline
\end{tabular}

\section{Language of the Articles and Naming of the Concept}

Table 5 exhibits the terms used for edutainment in Turkish. Approximately two-thirds of the articles (16 articles) were published in Turkish, whereas nearly one-third of them ( 9 articles) were published in English.

It is seen that approximately half of the articles just used the English term (edutainment) instead of the Turkish term (eğitlence) without any translation effort into Turkish. The most commonly used namings in Turkish consists of the terms that can translated into English as 'entertaining education' and 'education by entertainment.' Besides the Turkish word for entertainment, a version of the word learning in Turkish was also used in an article. In other articles, some namings were used by combining or uniting the words 'entertaining' and 'education.'

Table 5. Language and Naming for Edutainment

\begin{tabular}{lclc}
\hline Naming of Edutainment in Turkish & $\mathbf{f}$ & Language & $\mathbf{f}$ \\
\hline Edutainment & 11 & Turkish & 16 \\
Entertaining education (Ĕglenceli eğitim) & 6 & English & 9 \\
Education by entertainment (Eğlendirirken eğitim) & 3 & & \\
Education and entertainment (Eğitim ve eğlence) & 1 & & \\
Entertainment-learning (Eğlence-öğrence) & 1 & & \\
Edu-tainment (Eğitlence) & 1 & & \\
Educating entertainment (Eğitici eğlence) & 1 & & \\
Amusing education (Eğlenceli-eğiti) & 1 & & $\mathbf{2 5}$ \\
Total & $\mathbf{2 5}$ & & \\
\hline
\end{tabular}




\section{Approaches towards Edutainment}

Table 6 shows the general approach towards edutainment in the articles analyzed in such dimensions as positive, cautious-positive and critical-negative. The relevant approaches are expressed within the context of the sub-themes on Table 7. In general, there is a positive approach in nearly all of the articles ( 23 articles). There is a critical and negative approach only in two articles. As for the sub-themes, the positive impact on learning were highlighted in 23 articles and it was stated only in 4 articles that it's likely to create negative impact on learning. It was pointed out in three articles that there should be more studies on edutainment, whereas the need for technical improvements on practices of edutainment is indicated in 7 articles. The impact of environmental conditions was discussed in two articles.

The quotations from certain articles with a positive approach towards edutainment are as follows:

Games to turn education into edutainment. When we consider the characteristics of young children, edutainment would be a better term rather than education (Korkmaz, 2012)

Teaching can be made easier by attracting the learners' attention and making the subject and information to be taught more enjoyable with the edutainment approach (Aksakal, 2014)

Although some people access information whenever they want in today's world, there are also many people who fail to use information technologies and thus access information. Television is the source of information to many people but this situation could be resolved with the ETV and the digital divide could be prevented. Self learning - Learning at Home (Ozan, 2004).

The quotations from the articles consisting of positive, yet cautious approaches towards education, are as follows:

Digital games comprise of both advantages and disadvantages. What's important is to transfer digital games into the process of education at the right time, in direct proportion, in a planned manner and in line with certain objectives (Bozkurt, 2014)

Table 6. General Approach towards the Edutainment Phenomenon

\begin{tabular}{ll}
\hline General Approach towards Edutainment & $\mathbf{f}$ \\
\hline Positive & 20 \\
Cautious/Positive & 3 \\
Critical/Negative & 2 \\
Total & $\mathbf{2 5}$ \\
\hline
\end{tabular}

The views on the issue are reflected in various dimensions by certain quotations from the articles highlighting the positive impacts of edutainment on learning;

It was observed that it makes the children's process of learning more interesting (Atesci \&Islamoglu, 2014)

More importance should be attached to dimensions of the web-based learning. The finding of a positive impact, satisfaction from the class (Argan, 2009) 
(Participants of the research) said that an entertaining atmosphere has been created, there is a positive impact on learning (Basarmak \& Mahiroglu, 2015)

(Participants) (Believe that) the education through educational games created an entertaining atmosphere of learning (Batdi, 2012)

The educational computer games could be combined with other learning methods, and thus learning could be achieved as a whole (Catak, 2011)

It was seen that the studies conducted with regard to atmospheres of customizable learning were applied usually on the level of secondary education and higher education. It's suggested that these applications are used in previous levels. The atmospheres of customizable learning are gradually getting more widespread and popular. It's considered that the web 3.0 and semantic web technologies would make great contributions to such atmospheres with the advancement of technology (Sahin \& Kisla, 2013)

Table 7. Sub-themes of Approaches towards Edutainment

\begin{tabular}{ll}
\hline Themes & $\mathbf{f}$ \\
\hline Positive effects on learning & 23 \\
Negative effects on learning & 4 \\
Adaptation to the entertaining environment & 1 \\
Reflections of popular culture & 1 \\
Edutainment as a research field & 3 \\
Technical Support & 7 \\
\hline
\end{tabular}

Some views evaluated in the sub-theme of negative impacts on learning could be indicated as follows:

In the process of preparing software with a hybrid design such as the entertaining education software, the educational objects and entertaining elements should be prevented from clouding each other and it should be remembered that the main purpose is to achieve the learning goals (Kara, 2007).

However, one unforeseen danger of adapting computer technology into education so enthusiastically is that learning is seen as fun and entertainment. Learners who are exposed heavily to the Internet, video games and ready-made images presented by multimedia develop a new attitude towards learning. As Bloom and Hanych (2002) observe, equating learning with fun suggests that if students are not enjoying themselves, they are not learning. In other words, learning becomes an obstacle that learners need to overcome. To Bloom and Hanych, "such an approach doesn't promote learning; it trivializes the learning process" (Okan, 2003).

Some opinions within the context of the sub-theme of adaptation to the entertaining environment are as follows:

It has been seen that various kinds of augmented reality applications on each level and for many needs in the educational environments started to be commonly used throughout the world (Cetinkaya \& Akcay, 2013). 
The augmented reality is capable of turning both the digital environment and physical space into a basis for games, it's much more interesting than the hybrid games, and it will be possible to see its effective examples in the near future (Catak, 2011)

There are certain opinions evaluated in the sub-theme of technical support, which are indicated below:

In today's Turkey, some investments are made and arrangements and studies are conducted in order to enable students to make educational subjects more meaningful in the process of education and teaching. Nevertheless, it's hard to say in what ways the computers without any educational software designed and developed in accordance with the intended population could provide the students with educational benefits (Inal \& Kiraz, 2008).

The views evaluated in the sub-theme of reflections of the popular culture could be exemplified as follows:

The concepts of 'edutainment' or 'infotainment,' deriving from various combinations of English words education, information and entertainment, which are often used in the nature and scientific documents, both highlight the entertainment, namely, the superior ideology of television to some extent, and also refer to the public broadcast's mission to inform and educate. Although the 'infotainment' or 'edutainment,' which are one of the important foundations of popular culture, appear as the concepts that combine information, education and entertainment, it's significantly indicated in academic literature that the information is sacrificed to entertainment in mass media. The concern for entertaining seems to have thoroughly penetrated into the texture of mass media. Concerns/requirements for having people 'watch,' 'like' and 'selling' (Narmanlioglu, 2011).

\section{Discussion}

Postman (2013, p.26) divides cultures into three types: tool-using cultures, technocracies and technopolies. Technopoly is the order consisting of the submission of all forms of cultural life to the sovereignty of technique and technology (Postman, 2013, p.54). According to Postman (1993; 2013), USA is the only society that is transformed to technopoly and some European countries and Japan are striving to be technopolies. Obviously, Turkey is not one of the technopolies as defined by Postman (1993) but we can extend Postman's conceptualization to include Turkey, at least within the context of education. The edutainment applications could be considered as one of the signs of being a prospective technopoly in terms of Turkey, in which technology and entertaining elements find their place with regard to education. According to findings of this research, the concept of edutainment and the studies covering edutainment are quite new for Turkey.

Similarly, the number of articles published regarding edutainment are quite few as the concept of edutainment dates back to a longer time throughout the world. There are 284 studies entitled edutainment from the WOS review (2016). The first study is the publication prepared by Molnar and Deringer in 1984. 10 studies were published in 1990s, 163 studies in 2000-2010 and 110 studies in the period of 2011-2016 with regard to edutainment (WOS, 2016). Concerning specifically the WOS, the increase that occurred especially in the number of studies 
on edutainment throughout the world in 2000-2010 created an impact on an increase in the number of articles on edutainment published in Turkey after 2010.

In Postman's words (2013, p.13), "new things require new words." As something other than education in its original sense has emerged, a new name should be found for that. As indicated in one of the articles analyzed, edutainment is a word better than education in order to define the thing experienced by the young people today. According to findings of this study, it was highlighted that it refers to a new understanding aimed at combining education and entertainment. The combination of education and entertainment has been often mentioned. This situation is likely to confirm Postman's finding (1985) that entertainment is making increasing inroads into people's personal lives (cited in Singhal \& Rogers, 2002). It is seen that there is not a common stance towards the Turkish definition of the concept in articles covering edutainment in Turkey. It is observed that the concept is used in English in many studies, whereas different definitions comprising of the combination of the Turkish words of education and entertainment are made in certain studies. According to Sahin's (2009) findings, the use of edutainment in press is also in the form of education by entertainment in computer environment. In this regard, it could be said that there is yet to emerge an accumulation in the context of meaning and definition of the concept. It could be actually argued that producing new concepts with the combination of the concepts of entertainment and education is not quite consistent. Indeed, the best name to be designated for a non-confusing education without any precondition and comment is the word entertainment (Postman, 2006, p.182).

According to findings of the study, there is a higher number of qualitative studies conducted regarding edutainment. It could be said that the qualitative paradigm has been gradually preferred in terms of academic studies in Turkey but the increase in the number of qualitative studies falls behind the general tendency throughout the world. In this regard, it's striking that the qualitative method have been further used in studies regarding education. This situation could be seen as an indication of the need for a deep analysis based on the opinions of parties to the interaction between technology, entertainment and education. There's a need for more qualitative and quantitative studies regarding edutainment on various levels and samples. It was seen that the studies on edutainment are mostly prepared by one author. It could be said that there is a tendency towards an increase in the number of joint studies prepared by multiple authors. Accordingly, joint studies on the subject of education are significantly required to be prepared by authors from various disciplines as well. The multidimensional studies combining various disciplines could ensure that the concept of edutainment is understood in a much better manner. According to the results of this study 16 edutainmentrelated articles have been published in 14 different journals. Most of the journals featuring edutainment articles are usually from the field of educational sciences, social sciences and communications. Considering this fact, it can be concluded that there is a need for more multidisciplinary studies on edutainment in accordance with the nature of this phenomenon that cut across a wide range of study areas.

Postman (1993) stressed that the only way of improving education is to improve learning technologies in technopoly. Teachers from primary grades to college are increasing the visual stimulation of their courses and reducing the amount of exposition their students must cope with. They think that the principal means by which student interest may be engaged is entertainment (Postman, 2006, p.182). There are a number of indications that reflect such understandings in articles regarding edutainment. An analysis of the general approach towards edutainment in the articles included in the scope of this study shows that most of the articles consist of a strong and enthusiastic support, as well as a positive stance. It was stated in 
studies with a positive stance that particularly the trio of education, technology and entertainment would make learning more attractive, entertaining, interesting and permanent. It could be argued in Postman's words (2004) that there is such an understanding as "teaching as an amusing activity." The edutainment applications are considered as the best way of improving learning. It corresponds to findings in the body of literature that the edutainment applications lead to learning and motivation as well as enjoyment (Bertacchini et al., 2012). The remarks made by Postman $(1993 ; 2004)$ within the context of introducing televisions and computers into classrooms are likely to predict such findings; why televisions or computers should introduce into classrooms? The only answer is to make learning more attractive and effective. Being attractive does not need any justification in Technopoly. Bu this kind answers is always about technique but it is not about the essential question: education for what (Postman, 1993). Nevertheless, such questions as to whether students learn math in a better way thanks to computers fail to teach us anything; on the contrary, such questions divert our attention from social, intellectual or institutional crises to other directions. As a result, what's important with regard to computers or edutainment is not related with what sort of educational tools they are. What's important is how they change our understanding of education and slowly destroy the longstanding school structure (Postman, 2013, p.23).

In Postman's (2004) view, television for example does not offer only entertainment but it transforms everything to entertainment. Entertainment is meta-ideology for TV (cited in Sener, 2016). As Alver (2004) observed that the consequences of communication technologies, that Postman mentioned, with the developments in computer technology and especially the internet, are felt more strongly. In such an atmosphere, the expectation for rendering education and learning primarily entertaining has been gradually strengthened. As stressed by Conlon (2002), everything should be satisfactory in the consumption culture and regarding learning as a hard-earned victory is considered as quite boring (Conlon, 2002). As Postman (1998) expressed, every advantage a new technology offers, there is always a corresponding disadvantage. While the majority of educators believe that the combination of education and entertainment is important in terms of educational success, some educators are of the opinion that such a combination is quite difficult (Rapeepisam et al., 2006). Some of the articles reviewed stress that the small number of articles with a critical approach about education in line with Postman's approach are likely to lead to both advantages and disadvantages. In this regard, such concerns over the initiation of negative impacts on learning and education by the identification of learning and education with entertainment were shared, rather than the positive impact of edutainment on learning. Postman sees some problems beyond some side effects or negativities in the combination of education and entertainment.

Postman (2013) predicts that in the long run, television may bring a gradual end to the careers of schoolteachers. Schoolteachers have been part of the knowledge monopoly created by printing, and their existence will come to an end with the breaking up of that monopoly with new technologies. It could be considered that the information technologies and edutainment evoke a bad end in terms of educators. In this regard, the educators' optimism which is generally emphasized in the articles reviewed could be considered as quite interesting and weird. "Such enthusiasm always calls to my mind an image of some turn-of-the-century blacksmith who not only sings the praises of the automobile but also believes that his business will be enhanced by it" Postman (2013, p.15) says, thinking that such enthusiasm caused by introducing technology into classrooms and also all the transformation deriving from it is not reasonable. Postman's (2013, p.16) finding that in cultures that have a democratic ethos, relatively weak traditions and a high receptivity to new technologies, everyone is inclined to be 
enthusiastic about technological change is considerably relevant with the studies conducted on edutainment in Turkey.

According to Postman, from Confucius to Plato, Cicero, Lock or Dewey, no one thought that education would be successful with entertainment (Conlon, 2002). The improvements in electronic technology could ensure that the individual desires are fulfilled in a more perfect manner but it leads to some results related with simpler ways of entertainment. For example, although television is the most popular means of entertainment, it encourages more individual way of entertainment at home (Cakir, 2005). The impact of the entertainment concept on political information, namely, "just laugh, you don't need to remember," is also evident in education (Kim \& Vishak, 2008). Moreover, "Entertainment, involves communication featuring external stimuli; it provides pleasure to some people, though not of course to everyone; and it reaches a generally passive audience" (Bates \& Ferri, 2009). As stressed by Bates and Ferri (2009), despite the entertainment's central location in social life, academics have had negative approaches. Some academics consider entertainment and popular culture as the same concepts. A great many of academics have considered that as a trivial field of study. As a result, it could be said that multidimensional studies are required within the context of the relation between entertainment and education.

Some authors distinguish between entertainment and game. It was suggested that the relation between edutainment and play-learning should be considered separately. Buckingham argues (2005) that a lot of learning can be done through play but not all play is learning. Edutainment software is a great idea if it is used in the correct manner. Although the terms learning through play and edutainment are often used to refer to the same meaning, there are some differences between them (cited in Rapeepisam et al., 2006). Resnick (2004) suggests that people's best learning experiences come when they are engaged in activities that they enjoy and care about, the play and learning should be united and the concept of 'playful learning' is preferred rather than edutainment, explaining why he doesn't like edutainment as follows: "The problem is with the way that creators of today's edutainment products tend to think about learning and education. Too often, they view education as a bitter medicine that needs the sugar-coating of entertainment to become palatable. They provide entertainment as a reward if you are willing to suffer through a little education. I also have a problem with word "edutainment" itself. When people think about "education" and "entertainment," they tend to think of them as services that someone else provides for you. Studios, directors, and actors provide you with entertainment; while schools and teachers provide you with education. New edutainment companies try to provide you with both. In all of these cases, you are viewed as a passive recipient.

As emphasized in the articles analyzed, a market has emerged where the edutainment studies regarding the out-of-school learning activities turned into strong rivals competing with schools in terms of being entertaining and attractive. Contrary to schoolbooks, the educational materials designed for home should meet the parent's demands and capable of being worth the time spent by children, and the children should be able to have fun and have a good time thanks to such books. This is how the concept of edutainment has emerged. A hybrid mix of education and entertainment relies on visual materials, game-like formats and more informal, less didactic styles of address. Computers, online learning etc. are inevitably marketed as fun (Buckingham \& Scanlon, 2005). These new forms of edutainment are a glamorous alternative to the tedium of school work (Buckingham \& Scanlon, 2005). While the parents were being placed under increasing pressure to 'invest' in their children's education by providing additional resources at home, companies started to take a wider place in the market targeting 
this field. There has been a significant increase in the market of educational materials designed for domestic use (Buckingham \& Scanlon, 2005). The commercial involvement in out-of-schoollearning (Buckingham \& Scanlon, 2005). This situation shows a gradual increase in the commercial involvement in education. Education appears as a significant market for media companies (Buckingham \& Scanlon, 2005). The appearance of more individual and tailor-made forms of learning with the involvement of edutainment, computer technologies etc. into classrooms is enthusiastically welcome. Nevertheless, as indicated by Postman (2013, p.22), over four centuries, the peace between print and oral culture at schools is now facing the risk to be destroyed by computers. In this process, egocentrism is likely to be perceived as a virtue.

According to the findings of the TUIK (Turkish Statistical Institute) for 2013, children are surrounded with the new media. The majority of children who begin to use telephones at the age of 10 have their own computer and nearly half of them use Internet every day (Kilinc \& Kilinc, 2014). In other words, children are already living in a world dominated by technology and entertainment. Children come to school having been deeply conditioned by the television world. Children who cannot learn to read, organize their thoughts into logical structure even in a paragraph or attend to lectures for more than a few minutes at a time are all the casualties of the battle taking place between the world of television and printed publications (Postman, 2013, p.21). It is emphasized in most of the articles analyzed in this study that the out-of-theschool environment in which the individuals, young people and children live is gradually rendered more technological and entertaining and that the school should harmonize with this situation. Furthermore it is stated that the new out-of-the-school forms of learning have begun to develop in this way. It seems the predictions made by Postman and Weingartner (1993, p.154) are realized; "developments in electronic information processing make the school as it presently exists unnecessary."

The school's harmonization with the technological and totally entertaining world outside and the existence of more fun and permanent learnings outside the school makes the school weary. The Sesame Street could be displayed as the beginning of this process. For example, the "Sesame Street" that began in 1969 was embraced quite positively, as it ensured that children who had not yet been to school sit transfixed in front of a television screen and the television which has a function to entertain was used for educating activities. What's more, the style of television learning is by its nature hostile to the book learning and school-learning. Now we know that Sesame Street encourages children to love school, provided that the school is like Sesame Street (Postman, 2006, p.175). The school should be entertaining on the criteria of the entertainment world. The studies consisting of a critical approach towards the edutainment issue emphasize that the mentioned environment comprises of other qualities, besides being entertaining. There are some concerns that these elements have penetrated into schools with edutainment applications in an environment dominated by the popular culture elements based on the consumption culture. According to Postman's (cited in Alver, 2004) point of view, this is a natural result of the mechanization and technology. According to Postman, with mechanization and technology, homo economicus has aimed maximum profit so people are no longer seen as the children of God or citizens but they are considered as market factors and consumer (Alver, 2004).

A few studies, consisting of a positive but more cautious approach on the edutainment issue, emphasize the technical incompetences regarding edutainment. Moreover, it is suggested that although the edutainment applications create positive impact on learning, there is a lack of sufficient findings as to whether they lead to a better realization of learning, and thus further studies are required. It is seen that the critical approach in these studies are limited to 
emphasize that the edutainment should not replace the contact between teacher and student. As stressed by Anikina and Yakimenko (2015), there are certain considerations that generally educational technologies and specifically edutainment applications should not be seen by the supporters of edutainment in the body of literature as a replacement for the contact between teacher and student but used as the elements to support the student's learning.

It could be argued from Postman's perspective that the mentioned limited critical approaches fail to touch upon the essence of the matter. Media tend to become mythic. Cars, planes, TV, movies, newspapers - they have achieved mythic status because they are perceived as gifts of nature, not as artifacts produced in a specific political and historical context (Postman, 1998). As an example of this mythicizing, we can argue that the technological intervention into educational environments is not questioned but practical deficiencies are brought into the forefront by most of the articles analyzed. Nevertheless, the interaction between technology, entertainment and education deserves much more in-depth analyses. It is essential that such analyses are accompanied by a critical approach towards the nature of technological changes, because, on the contrary, has serious consequences: "New technologies alter the structure of our interests: the things we think about. They alter the character of our symbols: the things we think with. And they alter the nature of community: the arena in which thoughts develop" (Postman, 1993, p.20).

Technological change is not additive; it is ecological. "A new technology does not add or subtract something. It changes everything." After television, America was not America plus television. Television gave a new coloration to every political campaign, to every home, to every school, to every church, to every industry, and so on (Postman, 1998; Postman, 2013, p.22). As emphasized by Postman (1995), for example, the invention of the mechanical clock provided men with a new conception of time and the invention of the telescope brought a new conception of the space and scale. Each new technology changes and reshapes human consciousness (Kuyumcu, 2008). Embedded in every technology there are powerful ideas. To a person with a TV camera, everything looks like an image. To a person with a computer, everything looks like data (Postman, 1998). As a result, we are not talking about a kind of education in which entertainment is attached along with technology. In other words, the education+entertainment+technology, but something totally different, which is formed by the combination of these three. Accordingly, it would not be sufficient to mention the practical deficiencies or some possibly negative consequences.

According to Postman (1998; 2013, p.16) people believe that the advantages of new technologies are distributed among the population sooner or later but every new technology benefits some and harms others. It could be argued that there is lack of research about the accessibility of technology and edutainment applications at schools or home by the children from different socio-economic environments. Accessing such educational materials and edutainment creates differences between families due to financial conditions. There is not much information as to children's enthusiastic engagement in such materials. "Anxious parents may represent a soft touch for marketers but children may not be so easily persuaded" (Buckingham \& Scanlon, 2005).

\section{Conclusion}

According to Postman (2004, 2013), childhood is going through a transformation. These transformations are closely related with technological developments. The first influence to 
childhood came from printing press, the second one from telegram (Alver, 2004; Postman, 1995, 2013). Now electronic media, computer technologies have more powerful effects on childhood's nature. Electronic media is demolishing the borders between childhood and adulthood. Clothes, alcohol use, crimes, sexual relationship are now common among children and adults (Alver, 2004). It could be argued that an analysis of such transformation and technological developments within the context of entertainment and education is a quite meaningful and necessary effort.

Accordingly, in this article, which aimed to discuss and evaluate the tendencies of edutainment in the context of research studies carried out in Turkey, 22 studies were examined in following categories: years of publication, numbers of authors, naming of edutainment, method, type, field, approach towards edutainment, main results and suggestions. We can argue that despite the positive approach in most of the studies on education, a few critical studies remain quite limited within the context of Postman's (1993; 1995; 2013) criticisms on technology and entertainment. Postman's criticism is related with the essence, rather than being technical. As indicated in a great number of articles, there are only a few studies on the edutainment issue in terms of those who have a positive or a negative approach.

As part of the studies on edutainment in Turkey, in Postman's (1993) words, technophile researchers could be mentioned. It could be argued that there is an enthusiastic support for the education shaped by technology and entertainment. This situation also corresponds to Postman's (2013, p.59) finding that social science is a vigorous ally of technopoly. It seems that what is called as the "American optimism" by Postman (2013, p.17) has penetrated into us as well. As indicated by Ahioglu-Lindberg (2012), childhood in Turkey is in a modernization process, whose repercussions are ongoing in the form of the adaptation of technological developments into daily lives and educational environments. Nevertheless, there are sound reasons for being cautious and critical about education which is shaped by technology and entertainment.

As suggested by Milberry (2010, p.50), technology has been inspired both by the respect and fear since the break of modern dawn. Technology is on the one hand like the humanity's victory over nature, and on the other, it's like its impending doom (Kilinc \& Kilinc, 2014). As emphasized by Conlon (2002), technology without any philosophy is blind, and technology could bring us to some choices that we have not chosen. As a result, it is essential that a healthy philosophical stance on technology is developed specifically in terms of education and edutainment. It could be said that the beginning of this process refers to starting to think about the primary goal of education.

Postman (1993) indicates that education merely aims at providing students with a job in the US, which is an example of technopoly. In this way, the US educates itself to compete with the Japanese or the German economies. Such an approach reflects the understanding that the US is not a culture but merely an economy. The basic problem is somewhere out there. What's more, there are some efforts aimed at filling the gap with technology in the context of educational purposes (Postman, 1993). The question as to the basic purpose and function of education specifically in Turkey should be answered in a consistent and intellectually deep manner. The growth and material wellbeing should not be perceived as irrefutable facts as the criteria for everything. The educational dimensions of a humanitarian rise like the one mentioned by Postman $(2004 ; 2013)$ should be able to be discussed irrespective of the technological enthusiasm. 
Postman (2013) suggests that the competition between technological tools is actually their competition for the dominance of their world view in the background. We see it most evidently in schools. There are two major technologies at school which are unable to reconcile with regard to the control of students' minds; printed word and television. The printed word emphasizes logic, sequence, history, exposition, objectivity and discipline, whereas there is the world of television with its emphasis on imagery, narrative, presentness, simultaneity, intimacy, immediate gratification and quick emotional response (Postman, 2013, p.21). It could be argued that the competition in which the school is required to struggle and doomed to be beaten easily, has started right here. Entertainment versus tedious classes. Technopoly has no place for a transcendent purpose, meaning or cultural cohesion (Postman, 2013, p.65). The interaction between technology, entertainment and education fills the gap created by the lack of a transcendent purpose with its operational liveliness and tempting attractiveness. Educators and academics should keep in mind the negative impacts of a learning process shaped by technology and entertainment, and thus work to ensure that original learning processes are built on the basis of a critical understanding. Contrary to the rapid, widespread and apparent success of technology and entertainment; the presence of examples in which the humanitarian dimension of education should be emphasized both practically and scientifically, which is very essential.

According to the major findings of the present study, although the edutainment studies in Turkey reflect the general tendency in the world, there are only a few of them quantitatively. There is no consensus on the designation and definition of the concept of edutainment. It could be said that the edutainment studies in Turkey lack a critical perspective with regard to technology and entertainment, and there is a quite limited framework. In this respect, we can say that there is a strong need for critical studies that examines the interaction between education and entertainment along with both negative and positive aspects of edutainment practices.

\section{References}

Addis, M. (2005). New technologies and cultural consumption - edutainment is born! European Journal of Marketing, 39(7/8), 729-736.

Ahioglu-Lindberg, E. N. (2012). Cocuk yetiştirme acisindan Turkiye'deki cocuklugun tarihi. Pamukkale Universitesi Egitim Fakultesi Dergisi, 31(1), 41-52

Aksakal, N. (2015). Theoretical view to the approach of the edutainment. Paper presented at the 5th World Conference on Learning, Teaching and Educational Leadership (WCLTA 2014). Procedia - Social and Behavioral Sciences, 186, 1232-1239

Alver, F. (2004). Neil Postman'in cocuklugun yok olus surecinde iletisim teknolojisi elestirisinin elestirisi. Iletisim: Araştirmalari Dergisi, 2(2), 129-142

Anikina, O. V. \& Yakimenko, E. V. (2015). Edutainment as a modern technology of education. International Conference on Research Paradigms Transformation in Social Sciences 2014. Procedia - Social and Behavioral Sciences, 166, 475-479

Argan, M. T. (2009). Students' attitudes towards WEBCT applications in selected courses. Turkish Online Journal of Distance Education, 10(1), 47-56

Atesci, E. \& Islamoglu, G. (2014). Bir "Edutainment" uygulamasi: KidzMondo ornegi. 1. Uluslararası Illetisim Bilimi ve Medya Araştirmalari Kongresi, 2, 388-397 
Basarmak, U. \& Mahiroglu, A. (2015). Cevrimici ögrenme ortaminda kullanilan karikatur animasyonuna iliskin ogrenci gorusleri. International Journal of Eurasia Social Sciences, 6(19), 234-253

Batdi, V. (2012). Yabanci dil ogretiminde egitsel oyunlarin kullanilmasina iliskin ogretmen gorusleri. Egitim ve Ogretim Arastirmalari Dergisi - Journal of Research in Education and Teaching, 1(4), 317-324

Bates, S. \& Ferri, A. (2010). What's entertainment? Notes toward a definition. Studies in Popular Culture, 33(1), 1-20.

Bertacchini , F., Bilotta, E., Pantano, P., \& Tavernise, A. (2012). Motivating the learning of science topics in secondary school: A constructivist edutainment setting for studying Chaos, Computers \& Education, 59(4), 1377-1386

Bozkurt, A. (2014). Homo ludens: Dijital oyunlar ve egitim. Egitim Teknolojileri Araştirmalari Dergisi, 5(1), 1-21

Buckingham, D. \& Scanlon, M. (2005). Selling learning: Towards a political economy of edutainment media, Media, Culture and Society, 27(1), 41-58

Catak, G. (2011). Oynarken tasarlamak: Dijital tasarim oyunlari. Sigma, 3, 385-391

Cakir, V. (2005). Bir sosyal etkinlik olarak eglence ve televizyon: Konya ornegi, Selcuk Universitesi Sosyal Bilimler Enstitusu Dergisi, 1, 123-142.

Cetinkaya, H. H. \& Akcay, M. (2013, Ocak). Egitim ortamlarinda arttirilmis gerçeklik uygulamalari. Akademik Bilisim Kongresi'nde sunulan bildiri. Antalya: Akdeniz Universitesi.

Conlon, T. (2002). Bilgi teknolojisi, egitim ve postmodernizm. Eğitim Bilimleri ve Uygulama, 1 (2), 269-278

De Paolis, L. T., Aloisio, G., Celentano, M. G., Oliva, L., \& Vecchio, P. (2009). Design and development of a virtual reality application for edutainment in cultural heritage, 15th International Conference on Virtual Systems and Multimedia, VSMM '09, pp. 80-84. DOI: 10.1109/VSMM.2009.18

Goffe, W. L. \& Sosin, K. (2005). Teaching with technology: May you live in interesting times. The Journal of Economic Education, 36(3), pp. 278-291

Inal, Y. \& Kiraz, E. (2008). Bilgisayar oyunlari ideoloji içerir mi? Egitsel ve ticari oyunlara bakis. Turk Egitim Bilimleri Dergisi, 6(3), 523-544

Jarvin, L. (2015). Edutainment, games, and the future of education in a digital world. In E. L. Grigorenko (Ed.), The global context for new directions for child and adolescent development. New Directions for Child and Adolescent Development, 147, 33-40.

Kara Y. (2007). Eglenceli egitim yaziliminin ögrenci basarisina, kavram yanilgilarina ve biyolojiye karsi tutumlarina etkisi. Marmara Universitesi Ataturk Egitim Fakultesi Dergisi, 25, 129138.

Katz, D. L. (2015). Doctors, TV, and truth: Evidence in the realm of edutainment. Journal of Public Health Management Practice, 21(5), 422-425

Kilinc, B. \& Kilinc, E.P. (2014). Yeni medya ortaminda cocuk birey: Yeni iletisim teknolojileri ve medya pedagojisinin onemi. Akdeniz Iletişim Dergisi, 22, 9-23 
Kim, Y. M. \& Vishak, J. (2008). Just laugh! You don't need to remember: The effects of entertainment media on political information acquisition and information processing in political judgment. Journal of Communication, 58, 338-360

Korkmaz, S. C. (2013). Language games as a part of edutainment. Paper presented at 3rd World Conference on Learning, Teaching and Educational Leadership. Procedia - Social and Behavioral Sciences, 93, 1249-1253

Molnar, A. R. \& Deringer, D. K. (1984). Edutainment: How to learn to laugh and learn. IEEE Spectrum, 21(6), 114-118.

Narmanlioglu, H. (2011). Populer belgesellerde doganin sunumu: BBC Planet Earth serisi uzerine bir inceleme. Istanbul Universitesi Iletisim Fakultesi Hakemli Dergisi, 40, 53-65.

Okan, Z. (2003). Edutainment: Is learning at risk? British Journal of Educational Technology, 34 (3), 255-264

Ozan, O. (2004). Gelecek kusak ögrenme: T- ogrenme (t-learnig). XIII. Ulusal Egitim Bilimleri Kurultayı. Malatya: Inonu Universitesi Egitim Fakultesi.

Pembecioglu, N. (1997). Cocukluklarini yitiren cocuklar ustune. Istanbul Universitesi Iletisim Fakultesi Dergisi, 6, 253-277

Postman, N. (1993). Tecnopoly: The surrender of culture to technology. New York: Vintage Books

Postman, N. (1995). Cocuklugun yok olusu (Çev. K. Inal). Ankara: İmge

Postman, N. (1998). Five things we need to know about technological change. Retrieved on 10 March 2016 from http://www.sdca.org/sermons_mp3/2012/121229_postman_ 5Things.pdf

Postman, N. (2004). Televizyon olduren eglence (Çev. O. Akinhay). Istanbul: Ayrinti.

Postman, N. (2013). Teknopoli. Kulturun teknolojiye teslim olusu (Çev. M. E. Yilmaz). Ankara: Sentez.

Postman, N. \& Weingartner, C. (1971). Teaching as a subversive activity. New York: Delta Book.

Rapeepisam, K., Wong, K. W., Fung, C. C., \& Depickere, A. (2006). Similarities and differences between "learn through play" and "edutainment". Proceedings of the 3rd Australian Conference on Interactive Entertainment (pp. 28-32). Perth, Australia.

Resnick, M. (2004). Edutainment? No thanks. I prefer playful learning. Associazione Civita Report on Edutainment. Retrieved on 15 May 2016 from https://llk.media.mit.edu/ papers/edutainment.pdf

Singhal, A. \& Rogers, E. M. (2002). A theoretical agenda for entertainment-Education. Communication Theory, 12,117-135. DOi: 10.1111/j.1468-2885.2002.tb00262.x

Sorathia, K \& Servidio, R. (2012). Learning and experience: teaching tangible interaction \& edutainment. International Educational Technology Conference IETC. Social and behavioral sciences, 64, 265-274.

Sahin, T. E. (2009). Turk dilindeki yabanci kelimeler (Yayimlanmamis yuksek lisans tezi). Edirne: Trakya Universitesi Sosyal Bilimler Enstitusu. 
Sahin, T. \& Kisla, T. (2013). Kisisellestirilebilir ögrenme ortamlari: Literatur incelemesi. Egitim ve Ogretim Araştirmaları Dergisi - Journal of Research in Education and Teaching, 2(1), 81-91

Sener, N. S. (2016). Eglencenin gozetleme hali ya da eglence endustrisinde gorunen ya da goren olmak. TRT Akademi Eğlence Endüstrisi Sayisi, 1(1), 50-70.

Thompson, P. M. (2007). The influence of popular culture and entertainment media on adult education. New Directions for Adult and Continuing Education, 115, 83-90. DOI: 10.1002/ace. 270

Wirth, W., Hofer, M., \& Schramm, H. (2012). Beyond pleasure: Exploring the eudaimonic entertainment experience. Human Communication Research, 38, 406-428. DOI: 10.1111/j.1468-2958.2012.01434.x

WOS (2016). In the Web of Science platform. Retrieved on 15 March 2016 from https://apps. webofknowledge.com/

Yamamoto, M. \& Watanabe, T. (2013). Development of an edutainment system with interactors of a teacher and a student in which a user plays a double role of them. Journal of Information Processing, 54(4) 1677-1685

Correspondence: Filiz Goktuna Yaylaci, Assistant Professor, Department of Sociology, Faculty of Humanities, Anadolu University, Yunus Emre Campus, Eskisehir, Turkey 